\title{
Early Permian age of granite pebbles from an Eocene or Oligocene conglomerate of the Internal Rif belt (Alboran domain, Morocco): hypothesis on their origin
}

\author{
Philippe Olivier ${ }^{1, *}$ and Jean-Louis Paquette ${ }^{2}$ \\ 154 impasse de la Bergeronnette, 31240 l'Union, France \\ ${ }^{2}$ Université Clermont Auvergne, CNRS, IRD, OPGC, Laboratoire Magmas et Volcans, 63000 Clermont-Ferrand, France
}

Received: 3 May 2018 / Accepted: 22 July 2018

\begin{abstract}
Granite pebbles from an Eocene or Oligocene conglomerate lying on a Ghomaride nappe of the Internal Zones of the Rif belt (Alboran domain, Morocco) have been dated by U/Pb on zircon at $281 \mathrm{Ma}$. No granite pluton being known in the Rif belt nor in the neighbouring Betic Cordillera, the origin of these calcalkaline Kungurian (end of the Early Permian) granites is discussed. A provenance from a nearby unit presently drowned in the Alboran sea is likely. Comparisons with other circum-Mediterranean domains show that this late plutonism characterizes an original domain in the Variscan orogen.
\end{abstract}

Keywords: granite / Rif belt / Alboran domain / Variscan / U/Pb zircon / Kungurian

\begin{abstract}
Résumé - Âge Permien inférieur de galets de granite provenant d'un conglomérat éocène ou oligocène du Rif interne (Domaine d'Alboran, Maroc): hypothèses sur leur origine. Des galets de granites provenant d'un conglomérat éocène ou oligocène reposant sur une des nappes ghomarides des Zones Internes de la Chaîne rifaine (Domaine d'Alboran, Maroc) sont datés par U/Pb sur zircons à $281 \mathrm{Ma}$. Aucun pluton granitique n'étant connu dans le Rif ni dans les Cordillères bétiques voisines, cet âge Kungurien (fin du Permien inférieur) représente une donnée importante pour discuter l'origine de ces granites calco-alcalins. Une provenance à partir d'une unité proche aujourd'hui submergée en mer d'Alboran paraît la plus probable. Par comparaison avec les autres domaines circum-méditerranéens, ce plutonisme très tardif par rapport aux âges du Carbonifère supérieur et du Permien basal caractérisant une grande partie de Chaîne hercynienne, fait de l'ensemble bético-rifain un domaine original au sein de cet orogène.
\end{abstract}

Mots clés : granite / chaîne rifaine / domaine d'Alboran / hercynien / U/Pb zircon / Kungurien

\section{Introduction}

The Rif belt (northern Morocco) (Chalouan et al., 2008 and references herein) belongs to the Western Mediterranean alpine chain, with the Betics in southern Spain, Kabylias in northern Algeria, Peloritan Mounts in Sicily and Calabria in southern Italy. These now scattered belts are generally considered as remnants of the $\mathrm{AlKaPeCa}$ terrane (Bouillin et al., 1986) dismembered during the Miocene. The internal zones of the Rifian and Betic belts form the Alboran domain (originally the Alboran microplate of Andrieux et al., 1971) affected by both Variscan and Alpine deformations. This domain would have been initially located along the eastern

\footnotetext{
*Corresponding author: philippe.olivier1531@orange.fr
}

coast of the Iberian plate, to the south of the Sardinia-Corsica block (e.g., Rosenbaum et al., 2002). Contrary to other ranges around the Mediterranean sea, the Betic-Rif belt is characterized by the lack of granitic pluton. However, a first discovery of granitic pebbles in a Tertiary (post-Upper Ypresian) conglomerate belonging to the cover of the internal Rif was reported by Olivier et al. (1979). Later, other discoveries of granitic pebbles in Upper Oligocene-Lower Miocene conglomerates from various units of the Betic-Rif belt were mentionned by Martín-Algarra et al. (2000), Puglisi et al. (2001), Zaghloul et al. (2003) and Gigliuto et al. (2004). These authors proposed various origins for these granites either on the basis of paleogeographic considerations or on the basis of geochemical analyses. None of them have used geochronological arguments, these granites being of unknown or poorly defined ages. In this paper, we present a well-defined date of 


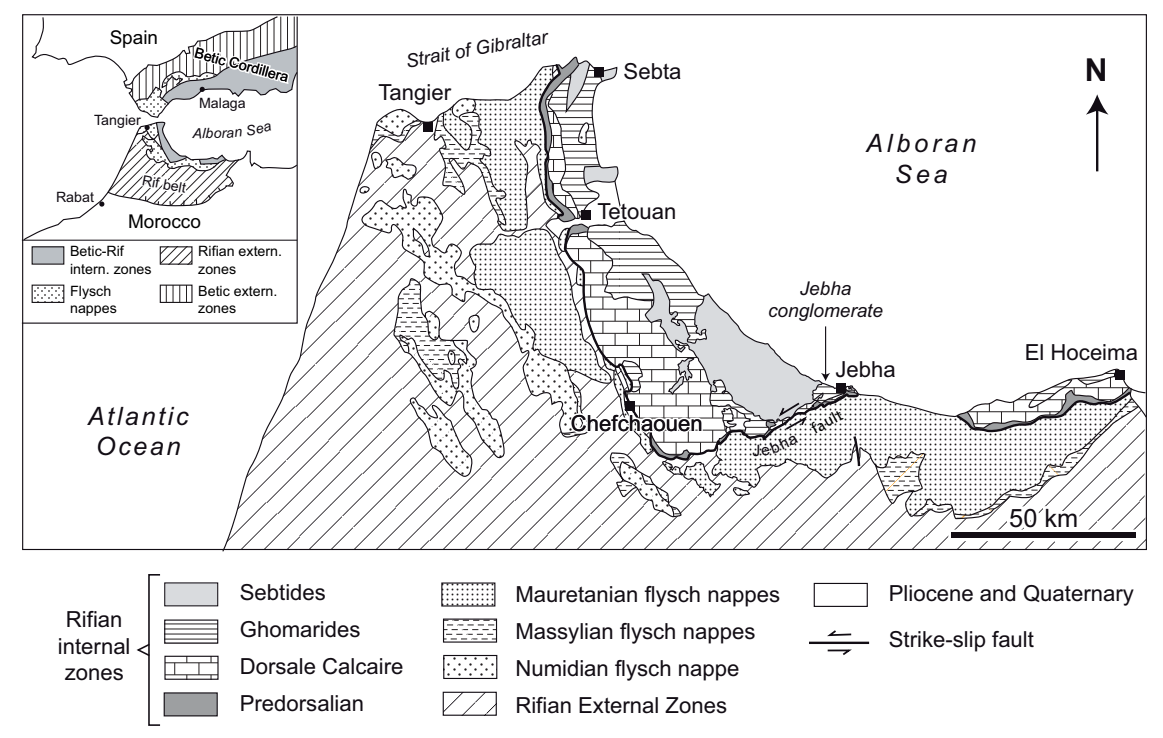

Fig. 1. Location of the Jebha conglomerate in the Internal Zones of the Rif chain.

the granitic pebbles mentionned by Olivier et al. (1979). On the basis of this new date and of geochemical analyses, we propose a possible origin for these granites.

\section{Geological setting}

The main units of the internal Rif (Fig. 1), and their equivalent in the western Betic Cordillera, are:

- the Sebtides (Rif) - Alpujarrides (Betics) constituted by the huge slices of mantellic peridotites of Beni Bousera and Ronda, kinzigites, HP paragneisses, rare orthogneisses and micaschists, Paleozoic or older in age, and a Permian and Triassic cover of metapelites and metacarbonates;

- the Ghomarides (Rif) - Malaguides (Betics) constituted by unmetamorphosed or slightly metamorphosed Paleozoic formations, with a thin Mesozoic and Paleogene up to Lowermost Miocene sedimentary cover;

- the Dorsale Calcaire formed by generally unmetamorphosed calcareous series of the Lower Mesozoic and Eocene to Upper Oligocene marly and conglomeratic formations;

- the Predorsalian units representing a transition zone between the Dorsale and the Flyschs domains.

The Flyschs nappes formed by Lower Cretaceous to Lower Miocene turbiditic series are located between the internal and external zones. The Rifian external zones correspond to the African foreland, and the Betic external zones correspond to the Iberian foreland.

The conglomerate containing the granitic pebbles studied in the present paper lies stratigraphically, but in a reverse position, on Paleozoic strata of a Ghomaride unit (Akaïli unit), $5 \mathrm{~km}$ to the WNW of Jebha (x: $\left.4^{\circ} 43^{\prime} 11^{\prime \prime} \mathrm{W}, \mathrm{y}: 35^{\circ} 13^{\prime} 00^{\prime \prime} \mathrm{N}\right)$ on the Mediterranean coast of central Rif (Fig. 1). This unit is here represented by Silurian schistosed pelites, Silurian to
Devonian paleovolcanic rocks, Devonian limestones and Triassic red sandstones and conglomerates (Fig. 2).

The Jebha conglomerate is represented by two neighbouring decametre-scale outcrops, displaying a dominantly red color, probably due to the Triassic red sandstones upon which this conglomerate was deposited. The matrix is composed of sandstones and pelites. The reworked elements are generally well rounded but poorly sorted, centimetre-scale up to one metre in diameter for some sandstones, up to fifty centimetres for the granites. These clasts (i.e., pebbles, cobbles and boulders in the Pettijohn (1975) classification) are composed of very various sedimentary, metamorphic, volcanic and plutonic rock types.

The sedimentary rocks are mainly sandstones and limestones. The most characteristic limestones are represented by Liassic dismicrites and by foraminifer-bearing limestones which were dated by Alveolina gr. oblonga, A. gr. minutula, $A$. cf. rutimeyeri, A. gr. tenuis or stipes and Nummulites granifer, $N$. campesinus, $N$. manfredi, $N$. leupoldi as Cuisian (Upper Ypresian) (Olivier, 1990, p. 134) giving then a maximum age to the conglomerate. The metamorphic rocks are quartzites and micaschists without characteristic minerals. The volcanic rocks are more or less weathered basalts of unknown age and origin. The plutonic rocks, i.e. various granite types, are described in the following section.

\section{Petrographic description and geochemical analyses of the granite pebbles}

Various facies of non-weathered two-mica granites were observed, with millimetre- up to a few centimetre-sized grains, i.e. fine-grain leucogranite, microgranite and more or less porphyritic granite (Fig. 3A-D). The paragenesis of most of these facies are similar with quartz, orthoclase and microcline, plagioclase, biotite and muscovite (primary and secondary). Some 


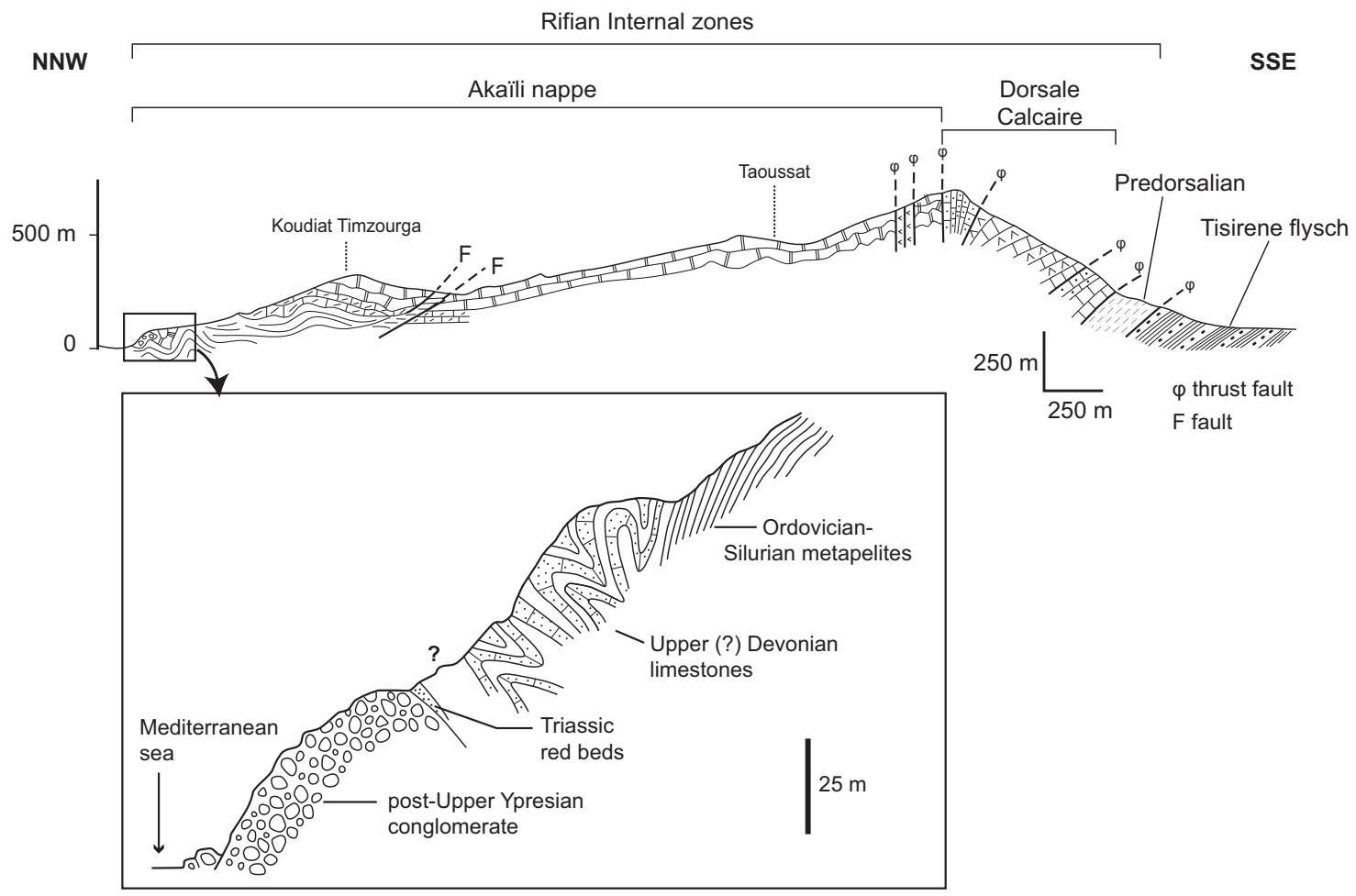

Fig. 2. Cross-section in the Internal Zones of the Rif Chain showing the position of the Jebha conglomerate.
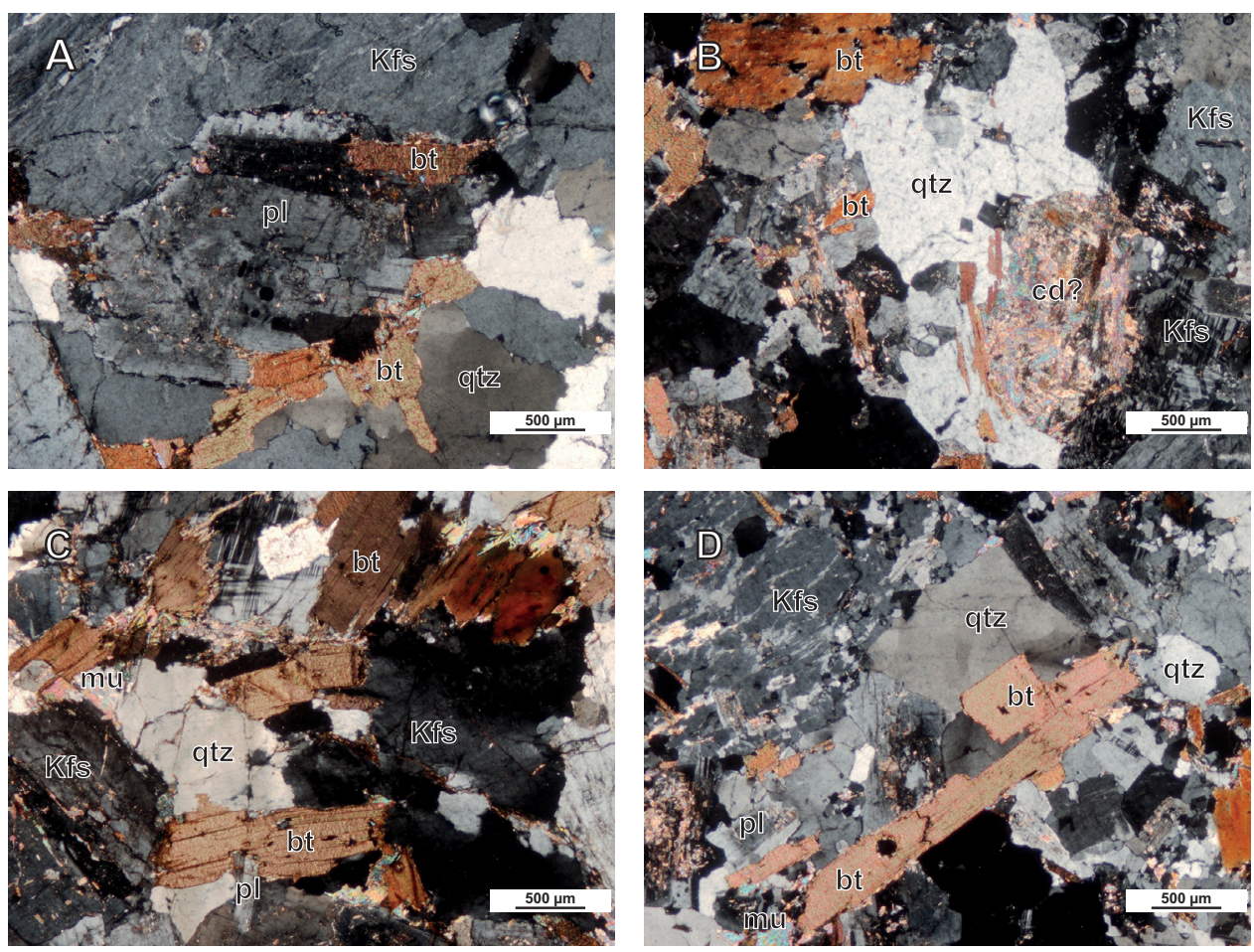

Fig. 3. Microphotographs of granites samples A: C2-4, B: CG, C: CF and D: CC from the Jebha conglomerate. Qtz: quartz; Kfs: K-feldspar; bt: biotite; mu: muscovite; cd?: cordierite pseudomorphosed into pinnite (?).

grains of tourmaline were observed in the leucogranites (samples $\mathrm{CB}$ and $\mathrm{C} 2-2$ ). Cordierite seems to be present as ghost crystals in some samples (CD and CG, Fig. 3B). Only the proportion of these minerals, especially K-feldspars vs. plagioclase and biotite $v s$. muscovite, may vary from one sample to another. The $\mathrm{CC}$ sample (Fig. 3D) contains a tiny enclave $(5 \times 3 \mathrm{~mm})$ of a rock composed of few grains of quartz, abundant more or less chloritized biotite and some grains of garnet. 
All these granites display magmatic texture, with a slight sub-magmatic deformation (chess-board texture in quartz grains, but undeformed or rarely kinked micas) in some samples. No oriented fabric nor solid-state deformation was observed.

Two samples of porphyritic granites (C2-4, Fig. 3A, and CG, Fig. 3B) were geochemically analysed (ALS Chemex Labs, Vancouver, Canada) (Tab.1). On a Shand diagram (A/NK vs. A/CNK) (Fig. 4) these samples plot in the peraluminous domain $(\mathrm{A} / \mathrm{CNK}>1)$, close to the I-type / $\mathrm{S}$ type boundary $(\mathrm{A} / \mathrm{CNK}=1.1)$. On a $\mathrm{Na}_{2} \mathrm{O}+\mathrm{K}_{2} \mathrm{O}$ vs. $\mathrm{SiO}_{2}$ diagram (TAS diagram) (Fig. 5) these granites plot in the calcalkaline domain.

The multi-element mantle-normalized spectra (Fig. 6a) of both samples are very similar with $\mathrm{Ba}, \mathrm{Nb}$ and $\mathrm{Sr}$ negative anomalies. The REE patterns (Fig. 6b) are also very similar, with a clear $\mathrm{Eu}$ negative anomaly and a rather strong fractionation with $(\mathrm{La} / \mathrm{Yb})_{\mathrm{N}}=11.85$ for $\mathrm{CG}$ and 8.88 for $\mathrm{C} 2-4$.

\section{Age of the granite pebbles}

\subsection{Analytical procedure}

In situ $\mathrm{U}-\mathrm{Th}-\mathrm{Pb}$ dating on zircon in thin sections of three samples of porphyritic granites, C2-4, CG and CF samples was performed by laser ablation inductively coupled plasma spectrometry (LA-ICP-MS) at Laboratoire Magmas \& Volcans (Clermont-Ferrand, France). The analyses involved the ablation of minerals with a Resonetics Resolution M-50 Excimer laser system operating at a wavelength of $193 \mathrm{~nm}$. Spot diameters of $26 \mu \mathrm{m}$ were used, associated with repetition rates of $3 \mathrm{~Hz}$ and a laser fluence of $4 \mathrm{~J} / \mathrm{cm}^{2}$. The ablated material was carried by helium and then mixed with nitrogen and argon before injection into the plasma source of an Agilent 7500 cs ICP-MS equipped with a dual pumping system to enhance sensitivity (Paquette et al., 2014). The analytical method for isotope dating is similar to that developed and reported in Hurai et al. (2010) and Paquette et al. (2017). The occurrence of common $\mathrm{Pb}$ in the sample was monitored by the evolution of the ${ }^{204}(\mathrm{~Pb}+\mathrm{Hg})$ signal intensity, but no common $\mathrm{Pb}$ correction was applied owing to the large isobaric interference from $\mathrm{Hg}$. Single analyses consisted of $30 \mathrm{~s}$ of background integration with the laser off, followed by $60 \mathrm{~s}$ integration with the laser firing and a $20 \mathrm{~s}$ delay to wash out the previous sample and prepare for the next analysis.

Data were corrected for U-Pb fractionation occurring during laser sampling and for instrumental mass bias by standard bracketing with repeated measurements of the GJ-1 zircon reference material (Jackson et al., 2004). Repeated analyses of the 91500 zircon reference material (Wiedenbeck et al., 1995) treated as an unknown independently control the reproducibility and accuracy of the corrections with a concordia age of $1067 \pm 3 \mathrm{Ma}\left(\mathrm{MSWD}_{(\mathrm{C}+\mathrm{E})}=0.45 ; n=69\right)$. Data reduction was carried out with the software package GLITTER $^{\circledR}$ from Macquarie Research Ltd (Van Achterbergh et al., 2001). Calculated ratios were exported and concordia ages and diagrams were generated using the Isoplot/Ex v. 3.23 software package of Ludwig (2001). The zircon analytical results (Tab. 2) were projected on ${ }^{207} \mathrm{~Pb} /{ }^{206} \mathrm{~Pb}$ versus ${ }^{238} \mathrm{U} /{ }^{206} \mathrm{~Pb}$ diagrams (Tera \& Wasserburg, 1972), where the analytical points plot along a mixing line between the common
$\mathrm{Pb}$ composition at the upper intercept and the zircon age at the lower intercept. This method is commonly used to date Phanerozoic zircons using in situ techniques (Baldwin and Ireland, 1995). The concentrations of $\mathrm{U}-\mathrm{Th}-\mathrm{Pb}$ were calibrated relative to the values of the GJ-1 zircon reference material (Jackson et al., 2004).

\subsection{Geochronological result}

Twenty-eight spots were performed on 22 zircons from the three selected samples. The analyzed zircons consist of euhedral and oscillatory zoned crystals (Fig. 7). They yield a discordia line with a lower intercept at $281.3 \pm 3.2 \mathrm{Ma}$ $(\mathrm{MSWD}=0.94)($ Fig. 7$)$. No older inherited core was detected during analyses. $\mathrm{U}$ and $\mathrm{Th}$ content are often particularly high and may reach concentrations of $4400 \mathrm{ppm}$ and $2660 \mathrm{ppm}$, respectively. This dating result corresponds to a Kungurian (end of the Early Permian) age.

Of course, the poorly defined ages of $85 \pm 3 \mathrm{Ma}, 174 \pm 5 \mathrm{Ma}$ and $194 \pm 6 \mathrm{Ma}$ (K-Ar on K-feldspar, on biotite and on muscovite, respectively) published by Olivier et al. (1979) must be considered as non-significant for the emplacement age of these granites.

\section{Discussion and interpretation}

The age of the Jebha conglomerate containing the granite pebbles here studied is unknown but considering the age of the foraminifer-bearing pebbles and the fact that the conglomerate was affected by folding of the Akailli nappe, it may be deduced that this conglomerate was deposited after the Late Ypresian and before the Late Oligocene which is the age of the first postnappe deposits (Fnideq formation) on the Internal Zones of the Rif chain (Feinberg et al., 1990). The age of folding and nappe stacking in the Ghomarides units is not precisely known but must be Latest Eocene or Oligocene in age because Upper Eocene (possibly Bartonian) marine limestones are found in the core of small synclines formed during this folding phase in the same region of Jebha (Olivier, 1990, p. 132).

The fact that many clasts from the Jebha conglomerate have decimetre-scale diameter and are poorly sorted points to a local origin and a short transport from the source areas. This hypothesis is reinforced by the fact that many pebbles display facies typical of the Ghomarides units and of the neighbouring internal Dorsale Calcaire such as the Liassic dismicrites and the alveoline- and nummulite-bearing limestones. The micaschists pebbles could be originated from the metamophic Sebtides units though they are not characteristic. The fact that one of our granite sample contains a micro-enclave of a garnetbearing micaschist could be an argument for an origin also from the Sebtides units, but these units have suffered a strong Alpine metamorphism, whereas the granite pebbles show no trace of such an event. The dates obtained by Olivier et al. (1979) on separate minerals of these granites may eventually be interpreted as an Alpine overprint, but the ages being very scattered $(85,174,194 \mathrm{Ma})$, no precise conclusion may be drawn.

The various studies, more recent than Olivier et al. (1979) study, on granite pebbles from the Betic-Rif belt have been made on samples of conglomerates belonging to the marine 
P. Olivier and J.-L Paquette: BSGF 2018, 189, 13

Table 1. Major and trace elements analyses of C2-4 and CG granite samples (this study) and of granite pebbles studied by Gigliuto et al. (2004).

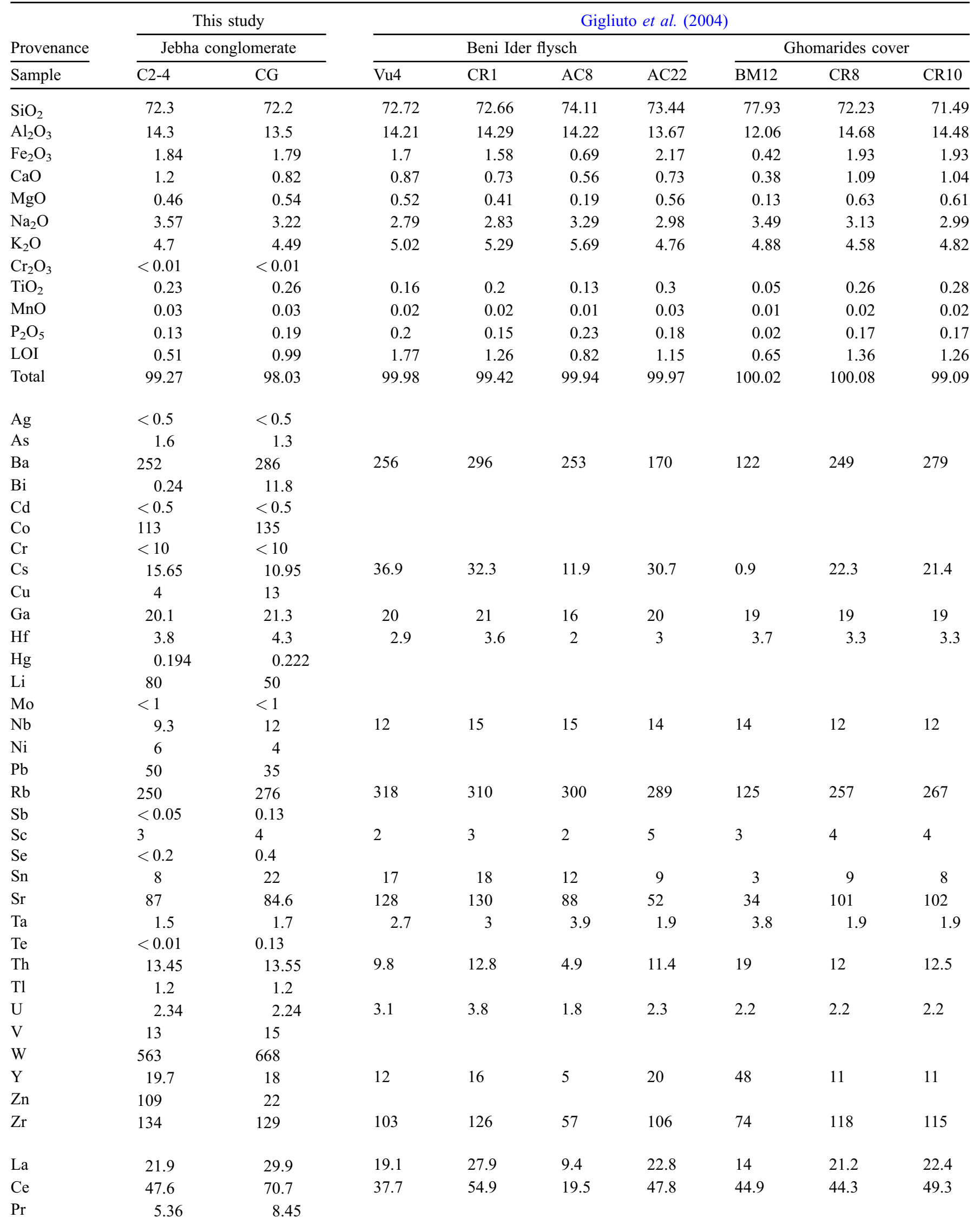


Table 1. (continued).

\begin{tabular}{|c|c|c|c|c|c|c|c|c|c|}
\hline \multirow{2}{*}{$\frac{\text { Provenance }}{\text { Sample }}$} & \multicolumn{2}{|c|}{$\begin{array}{c}\text { This study } \\
\text { Jebha conglomerate }\end{array}$} & \multicolumn{7}{|c|}{ Gigliuto et al. (2004) } \\
\hline & $\mathrm{C} 2-4$ & CG & $\mathrm{Vu} 4$ & CR1 & AC8 & $\mathrm{AC} 22$ & BM12 & CR8 & CR10 \\
\hline $\mathrm{Nd}$ & 21.4 & 33.1 & 15.9 & 23.3 & 8.1 & 21.4 & 14.4 & 19.8 & 21.5 \\
\hline $\mathrm{Sm}$ & 4.23 & 6.89 & & & & & & & \\
\hline $\mathrm{Eu}$ & 0.62 & 1.06 & 0.5 & 0.58 & 0.49 & 0.46 & 0.13 & 0.54 & 0.57 \\
\hline Dy & 3.45 & 3.64 & & & & & & & \\
\hline Но & 0.7 & 0.69 & & & & & & & \\
\hline Er & 2.06 & 1.65 & & & & & & & \\
\hline $\mathrm{Tm}$ & 0.27 & 0.26 & & & & & & & \\
\hline $\mathrm{Yb}$ & 1.77 & 1.81 & & & & & & & \\
\hline
\end{tabular}

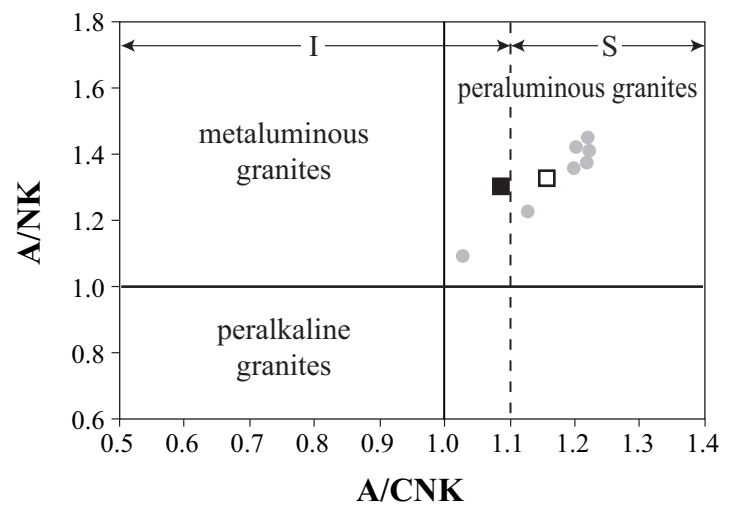

Fig. 4. A/NK vs. A/CNK diagram for the granites $\mathrm{C} 2-4$ (black square) and $\mathrm{CG}$ (white square) of this study, and for the granites (grey circles) studied by Gigliuto et al. (2004).

Upper Oligocene-Lower Miocene post-nappe cover of the Ghomarides (Fnideq formation) (Martín-Algarra et al., 2000; Puglisi et al., 2001; Zaghloul et al., 2003; Gigliuto et al., 2004) and of the Malaguides (Ciudad Granada formation) (MartínAlgarra et al., 2000), and from Upper Oligocene conglomerates of the Beni-Ider flysch (internalmost flysch nappe) (Puglisi et al., 2001; Gigliuto et al., 2004). Most of the granites studied by these authors are two-mica cordierite-bearing monzogranites and leucogranites, comparable to our samples, probably indicating a same origin, but only Gigliuto et al. (2004) have published chemical analysis of these rocks. Their compositions are remarkably similar, both for the major and trace elements, to the compositions of the granite pebbles from the Jebha conglomerate (Tab. 1). It just may be noted that most samples of Gigliuto et al. are slightly more peraluminous (Fig. 4). All these authors have admitted a local provenance (Ghomarides-Malaguides domain) of most pebbles from these conglomerates but the fact that granites and other rocks, such as orthogneiss, are unknown or poorly represented in the presently outcropping units led some of these authors to propose other origins for the granites. For Martín-Algarra et al. (2000), it could be a "lost realm" located to the east or south-

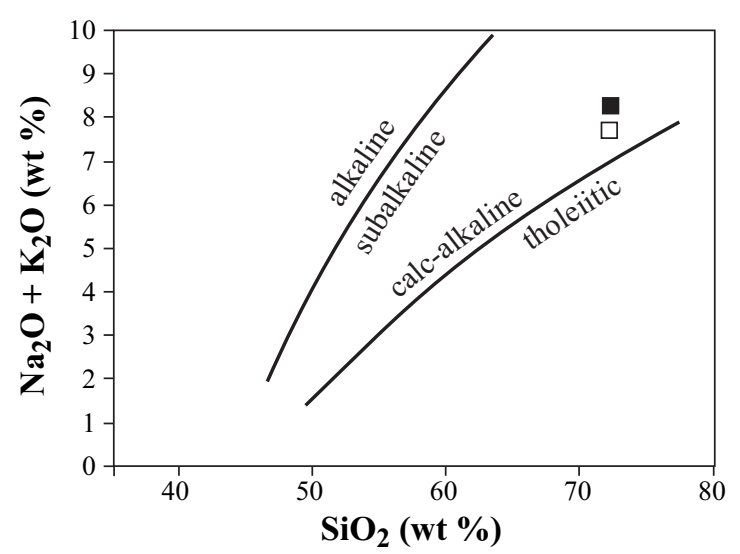

Fig. 5. $\mathrm{Na}_{2} \mathrm{O}+\mathrm{K}_{2} \mathrm{O}$ vs. $\mathrm{SiO}_{2}$ diagram for the granites $\mathrm{C} 2-4$ (black square) and $\mathrm{CG}$ (white square).

east of the present Betic-Rif belt and similar to the crystalline basement of the Kabylia-Calabria-Peloritani domain. A similar hypothesis was proposed by Puglisi et al. (2001). Conversely Gigliuto et al. (2004) exclude, on the basis of differences in Rb, $\mathrm{Sr}$ and $\mathrm{Ba}$ contents, the possibility of correlating the analysed granitoids with the plutonic rocks of the Calabria-Peloritani Arc and of the Kabylian massifs. They favour an origin of the granite pebbles in the Iberian Massif (central Spain and northern and central Portugal). Only Zaghloul et al. (2003) consider that all the pebbles were originated from the Ghomarides domain.

The $281 \mathrm{Ma}$ age of the granite pebbles from the Jebha conglomerate presented in this paper allows us to better discuss these hypothesis. Most of the granites from the Iberian Massif (e.g., Alvarado et al., 2013 and references therein), but also from the Moroccan Meseta (e.g., Michard et al., 2008 and references therein), and from the Calabria-Peloritani domains (e.g., Fiannacca et al., 2008) are Middle and Late Carboniferous to Earliest Permian in age, whereas granites as recent as $280 \mathrm{Ma}$ have been rarely characterized in these domains. However, Peucat et al. (1996) have dated at $278 \pm 3 \mathrm{Ma}(\mathrm{U} / \mathrm{Pb}$ on zircon) the Collo two-mica sillimanite- 

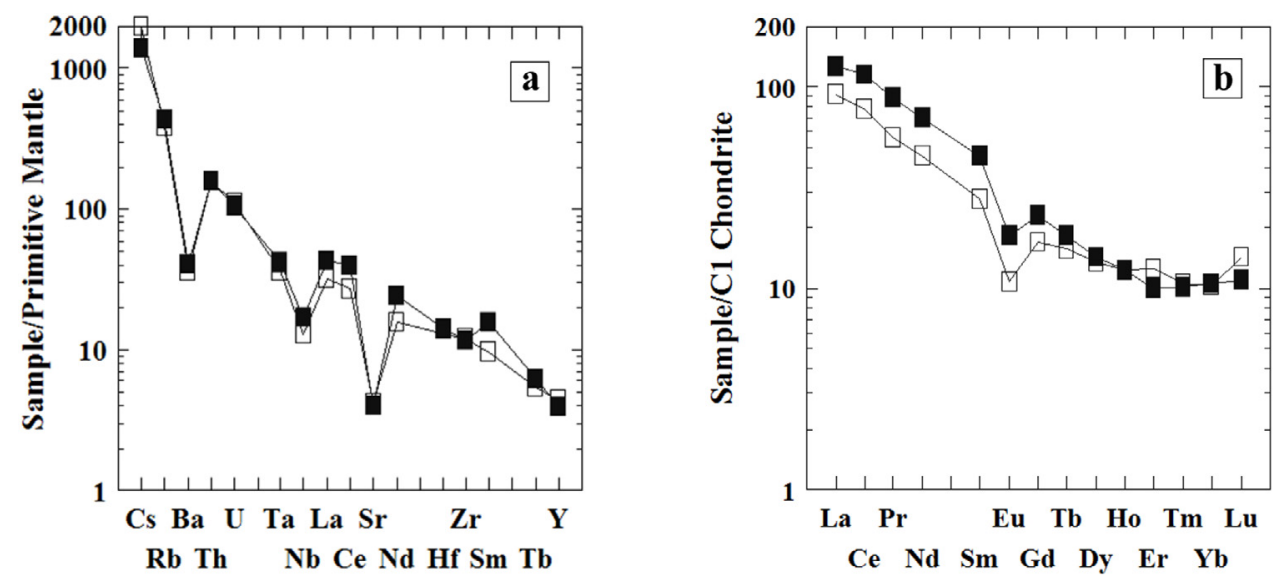

Fig. 6. a. Multi-element patterns normalized to the primitive mantle (Wood et al., 1979) for the granites C2-4 (black square) and CG (white square). b. REE patterns normalized to chondrite (Sun and McDonough, 1989) for the granites C2-4 (black square) and CG (white square).

Table 2. LA-ICPMS U-Pb zircon dating results.

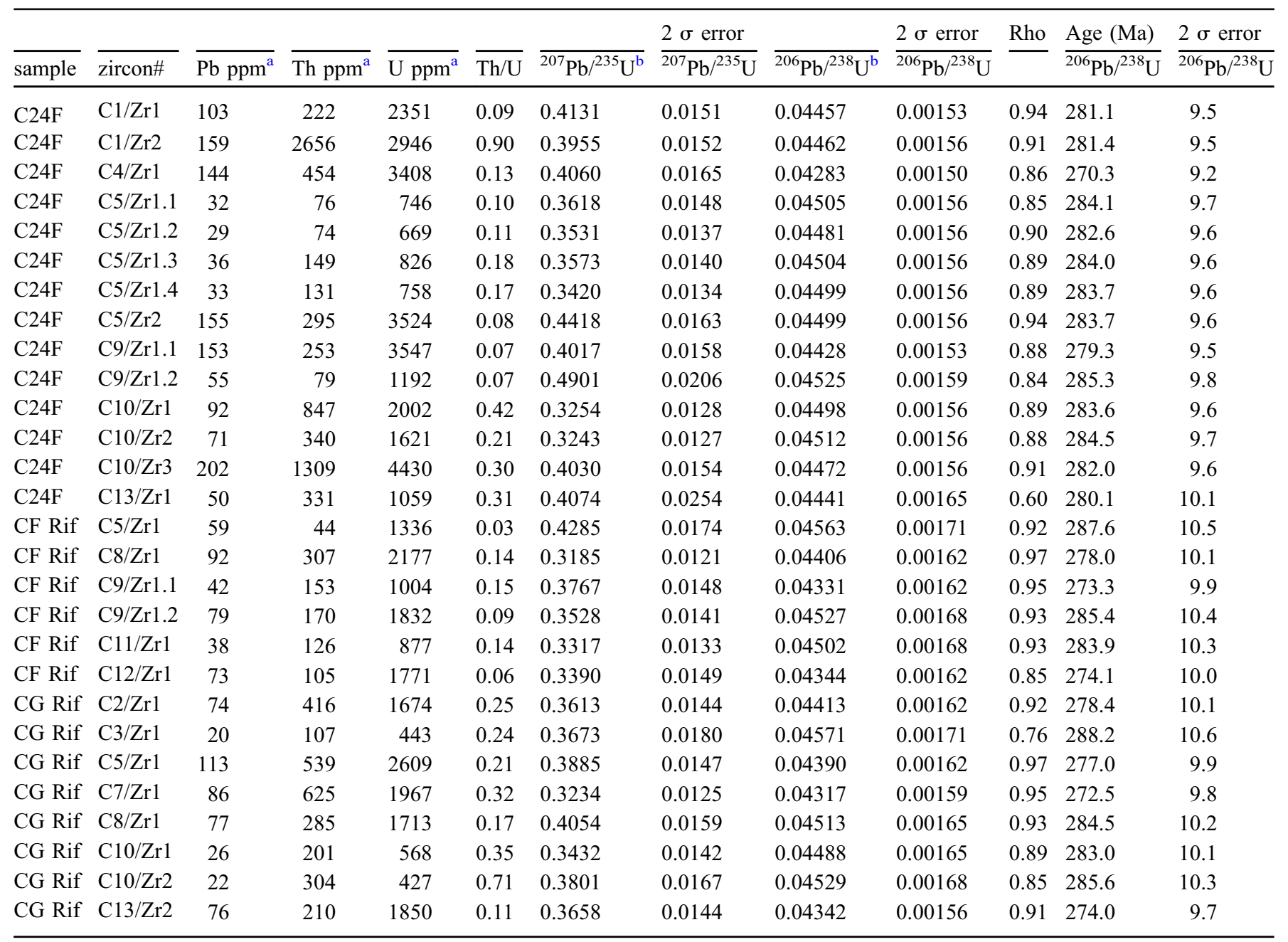

Decay constants of Jaffrey et al. (1971) used.

${ }^{\mathrm{a}}$ : concentration uncertainty c. $20 \%$.

${ }^{\mathrm{b}}$ : data not corrected for common- $\mathrm{Pb}$. 

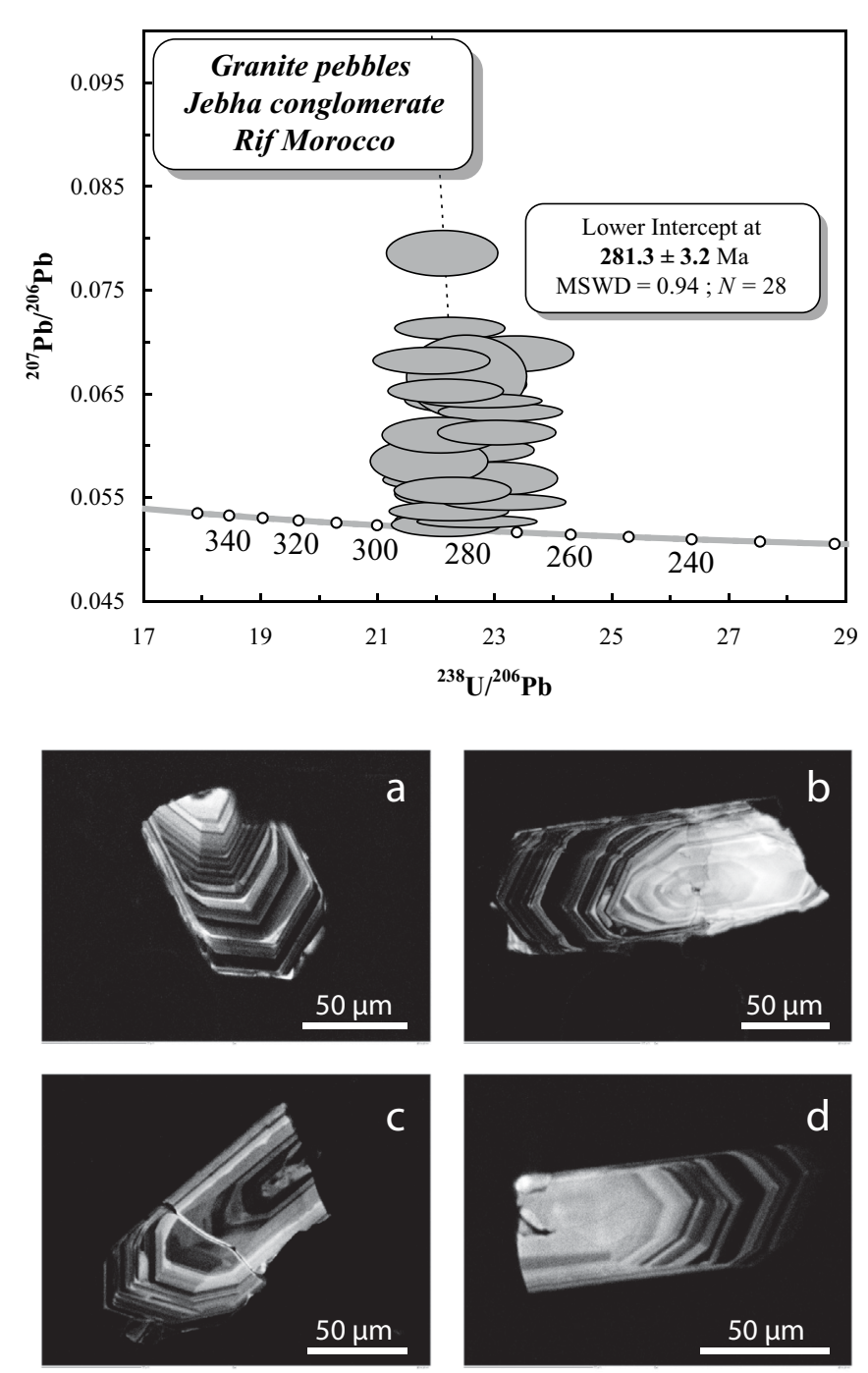

Fig. 7. ${ }^{207} \mathrm{~Pb} /{ }^{206} \mathrm{~Pb}$ vs. ${ }^{238} \mathrm{U} /{ }^{206} \mathrm{~Pb}$ Concordia diagram for the granite samples $\mathrm{C} 2-4, \mathrm{CF}$ and CG from the Jebha conglomerate. Microphotographs of representative zircons from $\mathrm{C} 2-4$ (a and b), CF (c) and CG (d).

bearing granite belonging to the upper units (greenschist facies) of the Internal domain of Lesser Kabylia, more or less equivalent to the Ghomarides units, and a dioritic enclave in the Sidi Ali Bou $\mathrm{Nab}$ granite of Great Kabylia at $284 \pm 3 \mathrm{Ma}$. Enrique and Debon (1987) have dated the Montnegre granitic pluton, in the Catalan Coastal Ranges, at 269 $\pm 4 \mathrm{Ma}$, whereas Solé et al. (2002) have obtained on the same pluton a cooling age at $285 \pm 3$ Ma but these ages obtained respectively by $\mathrm{Rb}-\mathrm{Sr}$ on whole rock and ${ }^{40} \mathrm{Ar} /{ }^{39} \mathrm{Ar}$ on biotite techniques would need to be confirmed by an U-Pb on zircon dating. Granites dated at about $280 \mathrm{Ma}$ are also known in Corsica (e.g. Paquette et al., 2003; Renna et al., 2007; Rossi et al., 2015) which could have been located close to the northeastern part of the $\mathrm{AlKaPeCa}$ domain (i.e., Calabria) (Rosenbaum et al., 2002) before the opening of the Alboran sea and Algerian and Provençal basins from the Early Miocene onwards. Farther from the Alboran domain Permian granites are known in the internal Alps, especially in the Sesia zone (Manzotti et al., 2014).
We have shown above that the numerous and large granite clasts of the Jebha conglomerate have certainly a local origin. Owing to their Kungurian age, these granites may be only compared to few granites from neighbouring regions (eventually Kabylias and Catalan Coastal Ranges), $280 \mathrm{Ma}$ old granites being mainly known in regions farther from the Rif (Corsica, Internal Alps), if one considers the former positions of the continents during the Eocene-Oligocene time. Consequently, we must admit that a large calc-alkaline granite pluton emplaced by the end of the Early Permian was outcropping during the Middle Eocene-Oligocene, and eventually during the Early Miocene, in a Ghomaride unit but that this unit was drowned in the Alboran sea during the Miocene opening of this basin. Until now, Variscan granites have not been found off-shore of the Betic-Rif belt, but highgrade metamorphic rocks similar to those of an Apujarride unit, associated with 22-19 Ma old granites, were cored at site 976 of Leg 161 (60 km south of Malaga) (Sánchez-Gómez et al., 1999), showing that at least a part of the floor of the Alboran basin is constituted by rocks of continental origin. It is thus very likely that other sites of the Alboran sea are constituted by Ghomarides-Malaguides-like units indicating that this domain is much larger than the on land outcropping zones and that a granite pluton could be present not far from the Rifian coast.

\section{Conclusion}

This first reliable date of granites from the Rifian internal zones presented in this paper represents a strong constraint for determining the origin of these granites. This result also shows that an important episode of plutonism occurred very late in this part of the Variscan domain. This plutonism was calc-alkaline and not alkaline contrary to most Permian plutonic rocks of the Variscan orogen (e.g., Denèle et al., 2012; Vacherat et al., 2017), probably characterizing an original domain in this orogen. Further studies will have to take these facts into account, but new datings on granite pebbles from the Betic-Rif belt and other part of the same chain (for instance in the Kabylias), and from outcropping granites of neighbouring regions (Moroccan meseta) where granites are often poorly dated, will be necessary to better characterize the end of the Variscan evolution of this orogenic domain. Another crucial problem, the exhumation age of the Rifian granites, would need to be studied by low-temperature thermochronology.

Acknowledgments. We thank Jean-François Mena for the thin sections, Christiane Cavaré for the drawings, Sophie Gouy for zircons microphotographs, Didier Béziat and Pierre Micoud for discussions about a first version of this paper. A. Michard and R. Leprêtre are acknowlegded for their constructive reviews.

\section{References}

Alvarado JD, Fernández C, Castro A, Moreno-Ventas I. 2013. SHRIMP U-Pb zircon geochronology and thermal modeling of multilayer granitoid intrusions. Implications for the building and thermal evolution of the Central System batholith, Iberian Massif, Spain. Lithos 175-176: 104-123. 
Andrieux J, Fontboté JM, Mattauer M. 1971. Sur un modèle explicatif de l'Arc de Gibraltar. Earth Planet Sci Letters 12(2): 191-198.

Baldwin SL, Ireland TR. 1995. A tale of two eras: PliocenePleistocene unroofing of Cenozoic and late Archean zircons from active metamorphic core complexes, Solomon Sea, Papua New Guinea. Geology 23: 1023-1026.

Bouillin JP, Durand-Delga M, Olivier Ph. 1986. Betic-Rifian and Tyrrhenian Arcs: distinctive features, genesis and development stages. In: Wezel FC, ed. The Origin of Arcs. Elsevier, Developments in Geotectonics 21: 281-304.

Chalouan A, Michard A, El Kadiri Kh, Negro F, Frizon de Lamotte D, Soto JI, et al. 2008. The Rif belt. In: Michard A, Saddiqui O, Chalouan A, Frizon de Lamotte D, eds. Continental evolution: the geology of Morocco. Lecture Notes in Earth Sciences. Berlin Heidelberg: Springer-Verlag, vol. 116, pp. 203-302.

Denèle Y, Paquette JL, Olivier Ph, Barbey P. 2012. Permian granites in the Pyrenees: the Aya pluton (Basque Country). Terra Nova 24: 105-113.

Enrique P, Debon F. 1987. Le pluton permien calcoalcalin de Montnègre (Chaînes Côtières Catalanes, Espagne): étude isotopique $\mathrm{Rb}-\mathrm{Sr}$ et comparaison avec les granites hercyniens des Pyrénées, Sardaigne et Corse. C R Acad Sci Paris 305(II): 11571162.

Feinberg H, Maate A, Bouhdadi S, Durand-Delga M, Maate M, Magné J, et al. 1990. Signification des dépôts de l'Oligocène supérieur-Miocène inférieur du Rif interne (Maroc), dans l'évolution géodynamique de l'Arc de Gibraltar. C R Acad Sci Paris 310(II): 1487-1495.

Fiannacca P, Williams IS, Cirrincione R, Pezzino A. 2008. Crustal contributions to Late Hercynian peraluminous magmatism in the southern Calabria-Peloritani Orogen, southern Italy: petrogenetic inferences and the Gondwana connection. J Petrol 49(8): 1497-1514.

Gigliuto LG, Ouazani-Touhami A, Puglisi D, Puglisi G, Zaghloul MN. 2004. Petrography and geochemistry of granitoid pebbles from the Oligocene-Miocene deposits of the internal Rifian chain (Morocco): a possible new hypothesis of provenance and paleogeographical implications. Geologica Carpathica 55(3): 261-272.

Hurai V, Paquette JL, Huraiová M, Konečný P. 2010. Age of deep crustal magmatic chambers in the intra-Carpathian back-arc basin inferred from LA-ICPMS U-Th-Pb dating of zircon and monazite from igneous xenoliths in alkali basalts. J Volcan Geotherm Res 198: 275-287.

Jackson SE, Pearson NJ, Griffin WL, Belousova EA. 2004. The application of laser ablation-inductively coupled plasma-mass spectrometry to in situ $\mathrm{U}-\mathrm{Pb}$ zircon geochronology. Chemical Geology 211: 47-69.

Jaffrey AH, Flynn KF, Glendenin LE, Bentley WC, Essling AM. 1971. Precision measurement of half-lives and specific activities of ${ }^{235} \mathrm{U}$ and ${ }^{238} \mathrm{U}$. Phys Rev C4: 1889-1906.

Ludwig KR. 2001. User's manual for Isoplot/Ex Version 2.49, a geochronological toolkit for Microsoft Excel. Berkeley (USA): Berkeley Geochronological Center, Special Publication 1a, 55 p.

Manzotti P, Ballèvre M, Zucali M, Robyr M, Engi M. 2014. The tectonometamorphic evolution of the Sesia-Dent Blanche nappes (internal Western Alps): review and synthesis. Swiss J Geosci 107: 309-336.

Martín-Algarra A, Messina A, Perrone V, Russo S, Maate A, MartínMartín M. 2000. A lost realm in the internal domains of the BeticRif orogen (Spain and Morocco): evidence from conglomerates and consequences for Alpine geodynamic evolution. Journal of Geology 108: 447-467.
Michard A, Saddiqi O, Chalouan A, Frizon de Lamotte D. 2008. Continental evolution: the geology of Morocco. Lecture Notes in Earth Sciences. Springer, vol. 116, 424 p.

Olivier Ph. 1990. Étude géologique et structurale de la région de Jebha (Rif, Maroc). La terminaison NE de l'accident de Jebha-Chrafate. Notes Mém Serv Géol Maroc 323: 117-191.

Olivier Ph, Cantagrel JM, Kornprobst J. 1979. Problèmes posés par la découverte de blocs de granite dans un conglomérat tertiaire, couverture de l'unité ghomaride d'Akaïli (Rif interne, Maroc). $C R$ Acad Sci Paris 288: 299-302.

Paquette JL, Ménot RP, Pin C, Orsini JB. 2003. Episodic and shortlived granitic pulses in a post-collisional setting: evidence from precise $\mathrm{U}-\mathrm{Pb}$ zircon dating through a crustal cross-section in Corsica. Chemical Geology 198: 1-20.

Paquette JL, Piro JL, Devidal JL, Bosse V, Didier A. 2014. Sensitivity enhancement in LA-ICP-MS by $\mathrm{N} 2$ addition to carrier gas: application to radiometric dating of U-Th-bearing minerals. Agilent ICP-MS Journal 58: 4-5.

Paquette JL, Ballèvre M, Peucat JJ, Cornen G. 2017. From opening to subduction of an oceanic domain constrained by LA-ICP-MS U-Pb zircon dating (Variscan belt, Southern Armorican Massif, France). Lithos 294-295: 418-437.

Pettijohn FJ. 1975. Sedimentary Rocks (3rd ed.). New York City: Harper and Row.

Peucat JJ, Mahdjoub Y, Drareni A. 1996. U-Pb and $\mathrm{Rb}-\mathrm{Sr}$ geochronological evidence for late Hercynian tectonic and Alpine overthrusting in Kabylian metamorphic basement massifs (northeastern Algeria). Tectonophysics 258: 195-213.

Puglisi D, Zaghloul MN, Maate A. 2001. Evidence of sedimentary supply from plutonic sources in the Oligocene-Miocene flyschs of the Rifian Chain (Morocco): provenance and paleogeographic implications. Boll Soc Geol Ital 120: 55-68.

Renna MR, Tribuzio R, Tiepolo M. 2007. Origin and timing of the post-Variscan gabbro-granite complex of Porto (Western Corsica). Contrib Mineral Petrol 154: 493-517.

Rosenbaum G, Lister GS, Duboz C. 2002. Reconstruction of the tectonic evolution of the western Mediterranean since the Oligocene. Journal of the Virtual Explorer 8: 107-126.

Rossi Ph, Cocherie A, Fanning CM. 2015. Evidence in Variscan Corsica of a brief and voluminous Late Carboniferous to Early Permian volcanic-plutonic event contemporaneous with a hightemperature/low-pressure metamorphic peak in the lower crust. Bull Soc géol Fr 186(2-3): 171-192.

Sánchez-Gómez M, Azañón JM, García-Dueñas V, Soto JI. 1999. Correlation between metamorphic rocks recovered from site 976 and the Alpujárride rocks of the western Betics. In: Zahn R, Comas MC, Klaus A, eds. Proceedings of the Ocean Drilling Program, Scientific Results 161(23): 307-317.

Solé J, Cosca M, Sharp Z, Enrique P. 2002. ${ }^{40} \mathrm{Ar} /{ }^{39} \mathrm{Ar}$ Geochronology and stable isotope geochemistry of Late-Hercynian intrusions from north-eastern Iberia with implications for argon loss in K-feldspar. Int J Earth Sci 91: 865-881.

Sun SS, McDonough WF. 1989. Chemical and isotopic systematics of oceanic basalts: implications for mantle composition and processes. In: Sanders AD, Norry MJ, eds. Magmatism in the Ocean Basins. Geol Soc, London Spec Public 42: 313-345.

Tera F, Wasserburg G. 1972. U-Th-Pb systematics in three Apollo 14 basalts and the problem of initial $\mathrm{Pb}$ in lunar rocks. Earth Planet $\mathrm{Sci}$ Lett 14: 281-304.

Vacherat A, Mouthereau F, Pik R, Huyghe D, Paquette JL, Christophoul F, et al. 2017. Rift-to-collision sediment routing in the Pyrenees: A synthesis from sedimentological, geochronological and kinematic constraints. Earth-Science Reviews 172: 43-74. 
Van Achterbergh E, Ryan CG, Jackson SE, Griffin WL. 2001. Data reduction software for LA-ICP-MS. In: P Sylvester, ed. Laser ablation-ICPMS in the earth science. Mineralogical Association of Canada 29: 239-243.

Wiedenbeck M, Allé P, Corfu F, Griffin WL, Meier M, Oberli F, et al. 1995. Three natural zircon standards for U-Th-Pb, Lu-Hf, trace element and REE analyses. Geostandards Newsletters 19: $1-23$.
Wood DA, Joron JL, Treuil M. 1979. A re-appraisal of the use of trace elements to classify and discriminate between magma series erupted in different tectonic settings. Earth Planet Sci Lett 45: 326-336.

Zaghloul MN, Gigliuto LG, Puglisi D, Ouazani-Touhami A, Belkaid A. 2003. The Oligocene-Miocene Ghomaride cover: petrosedimentary record of an early subsident stage related to the Alboran sea rifting (Northern internal Rif, Morocco). Geologica Carpathica 54(2): 93-105.

Cite this article as: Olivier P, Paquette J-L. 2018. Early Permian age of granite pebbles from an Eocene or Oligocene conglomerate of the Internal Rif belt (Alboran domain, Morocco): hypothesis on their origin, BSGF - Earth Sciences Bulletin 189: 13. 